\title{
An In Vitro Study on the Cytotoxicity and Genotoxicity of Silver Sulfide Quantum Dots Coated with Meso-2,3-dimercaptosuccinic Acid
}

\author{
Mezo-2,3-dimerkaptosüksinik Asitle Kaplanmış Gümüş Sülfit Kuantum \\ Noktalarının Sitotoksisitesi ve Genotoksisitesi Üzerine Bir In Vitro Çalışma
}

\author{
(D) Deniz ÖZKAN VARDAR1, (D) Sevtap AYDIN2, (D) ibrahim HOCAOĞLU33, (D) Havva YAĞCI ACAR4, (D) Nursen BAȘARAN2* \\ ${ }^{1}$ Hitit University, Sungurlu Vocational High School, Health Programs, Çorum, Turkey \\ 2Hacettepe University, Faculty of Pharmacy, Department of Pharmaceutical Toxicology, Ankara, Turkey \\ ${ }^{3}$ Koç University, Graduate School of Materials Science and Engineering, İstanbul, Turkey \\ ${ }^{4}$ Koç University, College of Sciences, Department of Chemistry, İstanbul, Turkey
}

\begin{abstract}
Objectives: Silver sulfide $\left(\mathrm{Ag}_{2} \mathrm{~S}\right)$ quantum dots (QDs) are highly promising nanomaterials in bioimaging systems due to their high activities for both imaging and drug/gene delivery. There is insufficient research on the toxicity of $\mathrm{Ag}_{2} \mathrm{~S}$ QDs coated with meso-2,3-dimercaptosuccinic acid (DMSA). In this study, we aimed to determine the cytotoxicity of $\mathrm{Ag}_{2} \mathrm{~S}$ QDs coated with DMSA in Chinese hamster lung fibroblast (V79) cells over a wide range of concentrations ( $5-2000 \mu \mathrm{g} / \mathrm{mL}$ ).

Materials and Methods: Cell viability was determined by 3-(4,5-dimethylthiazol-2-yl)-2,5-diphenyltetrazolium bromide (MTT) and neutral red uptake $(\mathrm{NRU})$ assays. The genotoxic and apoptotic effects of DMSA/Ag $2 \mathrm{~S}$ QDs were also assessed by comet assay and real-time polymerase chain reaction technique, respectively.

Results: Cell viability was $54.0 \pm 4.8 \%$ and $65.7 \pm 4.1 \%$ at the highest dose $(2000 \mu \mathrm{g} / \mathrm{mL})$ of $\mathrm{Ag}_{2} \mathrm{~S}$ QDs using the MTT and NRU assays, respectively. Although cell viability decreased above $400 \mu \mathrm{g} / \mathrm{mL}$ (MTT assay) and $800 \mu \mathrm{g} / \mathrm{mL}$ (NRU assay), DNA damage was not induced by DMSA/Ag S QDs at the studied concentrations. The mRNA expression levels of $p 53$, caspase-3, caspase-9, Bax, Bcl-2, and survivin genes were altered in the cells exposed to 500 and $1000 \mu \mathrm{g} / \mathrm{mL}$ DMSA/Ag S QDs.

Conclusion: The cytotoxic effects of DMSA/Ag 2 S QDs may occur at high doses through the apoptotic pathways. However, DMSA/Ag 2 SDs appear to be biocompatible at low doses, making them well suited for cell labeling applications.
\end{abstract}

Key words: Meso-2,3-dimercaptosuccinic acid coated silver sulfide quantum dots, genotoxicity, apoptosis

öz

Amaç: Gümüş sülfür $\left(\mathrm{Ag}_{2} \mathrm{~S}\right)$ kuantum noktaları $(\mathrm{QD})$, hem görüntüleme hem de ilaç/gen hedefleme için büyük aktiviteleri nedeniyle biyo-görüntüleme sisteminde oldukça gelecek vaad eden nanomalzemelerdir. Mezo-2,3-dimerkaptosüksinik asit (DMSA) ile kaplanmış $\mathrm{Ag}_{2} \mathrm{~S}$ QD'lerin toksisitesi hakkında yeterli çalıșma yoktur. Bu çalışmada Çin hamster akciğer fibroblast (V79) hücrelerinde DMSA ile kaplanmış $\mathrm{Ag}_{2} \mathrm{~S}$ QD'lerin geniş bir konsantrasyon aralığında $(5-2000 \mu \mathrm{g} / \mathrm{mL})$ sitotoksisitesini belirlemeyi amaçladık.

Gereç ve Yöntemler: Hücre canlılığı 3-(4,5-dimetiltiyazol-2-il)-2,5-difeniltetrazolium bromid (MTT) ve nötral kırmız alım (NRU) deneyleri ile belirlendi. DMSA $/ \mathrm{Ag}_{2} \mathrm{~S}$ QD'lerin genotoksik ve apoptotik etkileri sırasıyla komet analizi ve gerçek zamanlı polimeraz zincir reaksiyonu tekniği ile değerlendirildi.

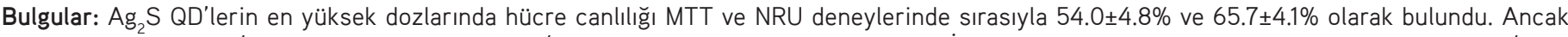
hücre canlılığı $400 \mu \mathrm{g} / \mathrm{mL}$ (MTT deneyi) ve $800 \mu \mathrm{g} / \mathrm{mL}$ (NRU deney) üzerinde azalmıștır. İncelenen konsantrasyonlarda DNA hasarının DMSA/Ag S QD'ler tarafından indüklenmediği belirlenmiștir. P53, kaspaz-3, kaspaz-9, Bax, Bcl-2 ve survivin genlerinin mRNA ekspresyon düzeyleri 500 ve 1000 $\mu \mathrm{g} / \mathrm{mL} \mathrm{DMSA} / \mathrm{Ag}_{2} \mathrm{~S}$ QD'lere maruz kalan hücrelerde değişmiştir.

Sonuç: DMSA/Ag $S_{2}$ QD'lerin yüksek dozlarda sitotoksik etkilerinin apoptotik yollarla ortaya çıkabileceği görülmektedir. Bununla birlikte, DMSA/ $\mathrm{Ag}_{2} \mathrm{~S}$ QD'ler, düşük dozlarda biyolojik olarak uyumlu görünmektedir, bu da onları hücre görüntüleme uygulamaları için uygun kılmaktadır.

Anahtar kelimeler: Mezo-2,3-dimerkaptosüksinik asit kaplı gümüş sülfür kuantum noktaları, genotoksisite, apoptoz

*Correspondence: E-mail: nbasaran@hacettepe.edu.tr, Phone: +90 3123052178 ORCID-ID: orcid.org/0000-0001-8581-8933

Received: 06.04.2018, Accepted: 31.05.2018

๑Turk J Pharm Sci, Published by Galenos Publishing House. 


\section{INTRODUCTION}

The number of commercial products containing nanoparticles (NPs) is rapidly increasing and NPs are already widely distributed in air, cosmetics, medicines, and even food. As one of the leading nanomaterials, engineered NPs are currently the focus of considerable research attention due to their various applications such as drug and gene delivery, biosensors, and diagnostic tools. The use of functional nanomaterials in biology and biomedicine has been extensively explored, and it has become one of the fastest moving and most exciting research directions. ${ }^{1,2}$

A key issue in evaluating the utility of these materials is assessing their potential toxicity, which may result from either their inherent chemical composition (e.g., heavy metals) or their nanoscale properties (e.g., inhalation of particulate carbon nanotubes).1.2 To date, a variety of nanomaterials, such as carbon nanotubes, silicon nanowires, gold/silver NPs, and quantum dots (QDs), have been studied and used in a wide range of biological applications..$^{3-6}$ NPs have unique features such as high surface-to-volume ratios, surface curvatures, and surface reactivities. They can also be produced with different sizes, chemical compositions, shapes, and surface charges, which affect their passage across the cell membranes, biodistribution, and toxicity. ${ }^{7-9}$ Recently, the use of nanomaterials has also attracted considerable interest in biomedical fields. ${ }^{10}$

QDs are nanometer-scale semiconductor crystals and are defined as particles with physical dimensions smaller than the exciton Bohr radius. QDs, which are composed of group II to VI or III to V elements, are often described as "artificial atoms". They exhibit discrete energy levels, and their band gaps can be precisely modulated by varying their size.1112 In 2002, Applied Spectroscopy published its first review on QDs, "Quantum Dots: A Primer," by Murphy and Coffer. ${ }^{13}$ The applications of luminescent nanocrystals have evolved tremendously over the last decade, particularly in bioimaging and bioanalysis. Since the first demonstration of QDs for biological imaging in 1998, 14,15 thousands of research articles on QDs have been published. Researchers have exploited the brightness, photostability, sizedependent optoelectronic properties, and superior multiplexing capabilities of QDs for a myriad of applications. ${ }^{16-21}$ Some of the prominent applications include in vitro diagnostics, energy transfer-based sensing, cellular and in vivo imaging, and drug delivery and theranostics. ${ }^{18,22,23}$ In parallel with these advances in bioimaging and bioanalysis, QDs have also evolved to provide greater flexibility and capability. ${ }^{24}$

QDs are usually synthesized using group II-VI materials, for example, cadmium telluride (CdTe) or cadmium selenide (CdSe). ${ }^{25,26}$ Structurally, QDs consist of a metalloid crystalline core and a "cap" or "shell" that shields the core and renders the QD bioavailable. QD cores can be fabricated using different materials with different band gaps for luminescence in the visible or near-infrared region (NIR). Cd or Zn chalcogenides such as $\mathrm{CdS}, \mathrm{CdSe}, \mathrm{CdTe}$, and $\mathrm{ZnS}$ are examples of group II-VI series of $\mathrm{QDs}^{27,28}$ with luminescence in the visible range; indium phosphate and indium arsenate are examples of group III-V series QDs with emission in the red to NIR. 29,30

A major limitation with respect to the clinical use of $Q D s$ is their potential toxicity due to their chemical composition and nanoscale features. ${ }^{29}$ The most popular QDs for biological applications are still based on CdSe core materials, which offer high quality and control over the spectroscopic properties of the nanocrystal. Despite several demonstrations of relatively nontoxic compositions being delivered to cells, concerns remain regarding the cytotoxicity of released cadmium ions and the associated oxidative stress. ${ }^{31-36}$

Within the last decade, tremendous efforts have been devoted to developing $\mathrm{Cd}$-free QDs. Silver sulfide $\left(\mathrm{Ag}_{2} \mathrm{~S}\right) \mathrm{QDs}$ emerged recently as new generation $Q D$ s satisfying both of these criteria., ${ }^{37,38}$ Hocaoglu et al. ${ }^{38}$ reported meso-2,3dimercaptosuccinic acid (DMSA)-coated $\mathrm{Ag}_{2} \mathrm{~S}$ QDs as one of the most strongly luminescent, anionic, Nl-emitting QDs. These particles were significantly internalized by HeLa cells and provided strong intracellular optical signals, suppressing autofluorescence. No reduction in the viability of HeLa cells and only $20 \%$ reduction in $\mathrm{NIH} / 3 \mathrm{~T} 3$ cells at concentrations up to $840 \mu \mathrm{g} / \mathrm{mL}$ were reported, which is quite unusual for a nonpegylated QD. QDs were found quite hemocompatible as well. This composition is of special interest with respect to numerous applications since surface carboxylic acids can be conjugated with target ligands or drugs, producing theranostic NPs.

In the present study, we performed a detailed toxicity analysis to investigate the potential cytotoxicity, genotoxicity, and apoptosis induced by DMSA $/ \mathrm{Ag}_{2} \mathrm{~S}$ QDs in Chinese hamster lung fibroblast (V79) cells. To have a relatively thorough toxicity analysis of DMSA/Ag $S$ NIR QDs, the MTT and neutral red uptake (NRU) assays were performed to evaluate the potential cytotoxicity; the comet assay was performed to assess the potential genotoxicity; the real-time polymerase chain reaction (RT-PCR) technique was used to evaluate the regulation of mRNA expression of tumor suppressor gene ( $p 53$ ), apoptotic genes (caspase-3, caspase-9, and Bax) and anti-apoptotic genes ( $\mathrm{BCl}-2$ and survivin). The data presented here are the first that give the cytotoxic, genotoxic, and apoptotic effects of DMSA/ $\mathrm{Ag}_{2} \mathrm{~S} \mathrm{QDs}$ in vitro. Since there is insufficient research on their toxicity, this study provides remarkable information for human health.

\section{MATERIALS AND METHODS}

\section{Chemicals}

The chemicals were purchased from the following suppliers: hydrogen peroxide (35\%) $\quad\left(\mathrm{H}_{2} \mathrm{O}_{2}\right)$ from Merck Chemicals (Darmstadt, Germany); 3-(4,5-dimethylthiazol-2-yl)-2,5diphenyltetrazolium bromide (MTT), acetic acid, dimethyl sulfoxide (DMSO), DMSA, Dulbecco's modified eagle's medium (DMEM), ethanol, ethidium bromide (EtBr), fetal bovine serum (FBS), low melting point agarose, L-glutamin, NR, sodium chloride $(\mathrm{NaCl})$, sodium hydroxide $(\mathrm{NaOH}), \mathrm{N}$-lauroyl sarcosinate, normal melting point agarose, silver nitrate 
$\left(\mathrm{AgNO}_{3}\right)$, trypsin-EDTA, triton X-100, penicillin/streptomycin, and phosphate buffered saline (PBS) from Sigma-Aldrich Chemicals (St. Louis, MO, USA); and sodium sulfide $\left(\mathrm{Na}_{2} \mathrm{~S}\right)$ from Alfa-Aesar (Thermo Fisher Scientific, Karlsruhe, Germany). Milli-Q water (18.2 MOhm) was used as the reaction medium.

\section{Preparation and characterization of DMSA/Ag $\mathrm{S}_{2}$ NIR QDs}

DMSA/Ag 2 S NIR QDs were prepared in a one-step reaction. A detailed description and characterization were reported previously by Hocaoglu et al. ${ }^{38}$ Briefly, $42.5 \mathrm{mg}$ of $\mathrm{AgNO}_{3}(0.25$ $\mathrm{mmol}$ ) was dissolved in $75 \mathrm{~mL}$ of deoxygenated deionized water. Then $113.89 \mathrm{mg}$ of DMSA $(0.625 \mathrm{mmol})$ was dissolved and deoxygenated in $25 \mathrm{~mL}$ of deionized water at $\mathrm{pH} 7.5$ and added to the reaction mixture. The $\mathrm{pH}$ was adjusted to 7.5 using $\mathrm{NaOH}$ and $\mathrm{CH}_{3} \mathrm{COOH}$ solutions $(2 \mathrm{M})$. The reaction mixture was stirred at $70^{\circ} \mathrm{C}$ for $4 \mathrm{~h}$. The prepared colloidal DMSA/Ag $\mathrm{S}$ QDs were washed with deionized water using Amicon-Ultra centrifugal filters ( $3000 \mathrm{Da}$ cut-off) and stored in the dark at $4^{\circ} \mathrm{C}$. In order to calculate the concentration of QDs, a few
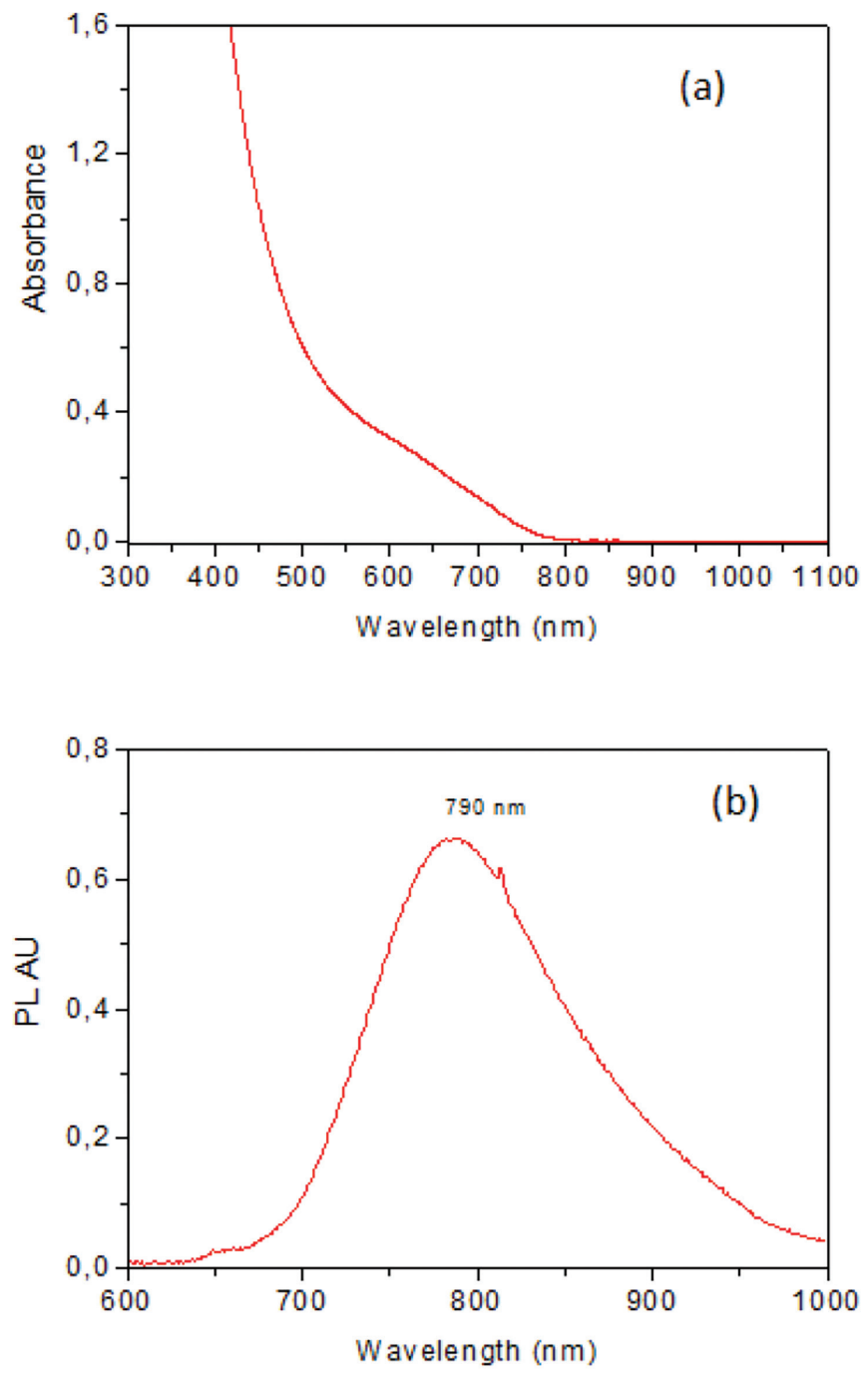

Figure 1. (a) Absorbance spectra, (b) emission spectra of colloidal DMSA/ $\mathrm{Ag}_{2} \mathrm{~S}$ QDs

$\mathrm{Ag}_{2} \mathrm{~S}$ : Silver sulfide, QDs: quantum dots milliliters of the colloidal solution was dried in a freeze-drier. The concentration of the QD solution was determined as 4.6 $\mathrm{mg} / \mathrm{mL}$. The absorbance spectrum of QDs was recorded in a Shimadzu 3101 PC UV-vis-NIR spectrometer in the 300-1000 $\mathrm{nm}$ range (Figure 1a). The photoluminescence spectrum was obtained as described in detail previously by Hocaoglu et al. ${ }^{38}$ Samples were excited with a DPSS laser operating at $532 \mathrm{~nm}$ and emission was recorded by an amplified silicon detector with femtowatt sensitivity in the range of $400-1100 \mathrm{~nm}$ with a lock-in amplifier. The QDs have an emission maximum at 790 $\mathrm{nm}$ with about $129 \mathrm{~nm}$ full-width at half maximum (Figure S1b). A Malvern zetasizer nano ZS was used for the measurement of the hydrodynamic size $(2.9 \mathrm{~nm})$ of aqueous $\mathrm{QDs}$ and the zeta potential of aqueous QDs $(-30 \mathrm{mV})$. Hydrodynamic size was measured by dynamic light scattering. No agglomeration in the cell culture medium was observed.

\section{Cell culture}

V79 cells were obtained from the American Type Culture Collection (ATCC; Rockville, MD, USA). The cells were grown in DMEM supplemented with 10\% heat-inactivated FBS, $1 \%$ penicillin/streptomycin solution (10.000 units of penicillin and $10 \mathrm{mg}$ of streptomycin in $0.9 \% \mathrm{NaCl}$ ), and $2 \mathrm{mM} \mathrm{L-glutamin}$ at $37^{\circ} \mathrm{C}$ in a humidified atmosphere of $5 \% \mathrm{CO}_{2} \cdot{ }^{39}$ The culture medium was changed every 3 to 4 days. The passage numbers used in our study were between 6 and 10 .

\section{Determination of cytotoxicity by MTT assay}

The MTT assay by the method described by Mosmann ${ }^{40}$ with the modifications by Hansen et al. ${ }^{41}$ and Kuźma et al. ${ }^{42}$ was carried out. The cells were disaggregated with trypsin/EDTA and then resuspended in the medium. The suspended cells (a total of $10^{5}$ cells/well) were plated in 96-well tissue-culture plates. The experiment was performed for 12 h, 24 h, and 48 h before and there were no time differences (data not shown). To get a dose range for the further experiments, $24 \mathrm{~h}$ incubation was selected. After the incubation for $24 \mathrm{~h}$, the cells were exposed to different concentrations of DMSA/Ag $\mathrm{S}$ QDs (5, 10, 25, 50, $100,200,400,200,800,1000,2000 \mu \mathrm{g} / \mathrm{mL}$ ) in the medium for $24 \mathrm{~h}$. Then the medium was removed and MTT solution $(5 \mathrm{mg} /$ $\mathrm{mL}$ of stock in PBS) was added (10 $\mu \mathrm{L} /$ well in $100 \mu \mathrm{L}$ of cell suspension). After the incubation of the cells for an additional 4 $\mathrm{h}$ with MTT dye, the dye was carefully taken out and $100 \mu \mathrm{L}$ of DMSO was added to each well. The absorbance of the plate was measured in a microplate reader at $570 \mathrm{~nm}$. The experiment was repeated three times. The results were expressed as the mean percentage of cell growth. $I C_{50}$ values represent the concentrations that reduced the mean absorbance of $50 \%$ of those in the untreated cells.

\section{Determination of cytotoxicity by NRU assay}

Determination of the cytotoxicity of DMSA $/ \mathrm{Ag}_{2} \mathrm{~S}$ QDs using $\mathrm{NRU}$ assay was performed according to the protocols described by Di Virgilio et al..$^{43}$ and Saquib et al. ${ }^{44}$ V79 cells were treated with DMSA/Ag 2 S QDs as described in the MTT assay. After incubation for $24 \mathrm{~h}$, the medium was aspirated. The cells were washed twice with PBS and incubated for an additional $3 \mathrm{~h}$ in 
the medium supplemented with NR $(50 \mu \mathrm{g} / \mathrm{mL})$. The absorbance of the solution in each well was measured in a microplate reader at $540 \mathrm{~nm}$ and compared with the wells containing untreated cells. The experiment was repeated three times. The results were expressed as the mean percentage of cell growth inhibition. $I C_{50}$ values represent the concentrations that reduced the mean absorbance of $50 \%$ of those in the untreated cells.

\section{Determination of genotoxicity by comet assay}

V79 cells were treated with DMSA/Ag ${ }_{2} \mathrm{~S}$ QDs as described in the MTT assay. Following the disaggregation of the cells with trypsin/EDTA and the resuspension of the cells in the medium, a total of $2 \times 10^{5}$ cells/well were plated in 6 -well tissue-culture plates. After $24 \mathrm{~h}$ of incubation, the cells were incubated with different concentrations of DMSA/Ag ${ }_{2} \mathrm{~S}$ QDs $(5-2000 \mu \mathrm{g} /$ $\mathrm{mL}$ ) for an additional $24 \mathrm{~h}$ at $37^{\circ} \mathrm{C}$. A positive control $(50 \mu \mathrm{M}$ $\mathrm{H}_{2} \mathrm{O}_{2}$ ) was also included in the experiments. The cells were embedded in agarose gel and lysed. Fragmented DNA strands were then drawn out by electrophoresis to form a comet. After electrophoresis, the slides were neutralized and then incubated in 50\%, 75\%, and $98 \%$ alcohol for $5 \mathrm{~min}$. The dried microscopic slides were stained with $\mathrm{EtBr}(20 \mu \mathrm{g} / \mathrm{mL}$ in distilled water, $60 \mu \mathrm{L} /$ slide) and were examined with a Leica ${ }^{\circledR}$ fluorescence microscope under green light.

The microscope was connected to a charge-coupled device camera and a personal computer-based analysis system (Comet Analysis Software, version 3.0, Kinetic Imaging Ltd, Liverpool, UK) to determine the extent of DNA damage after electrophoretic migration of the DNA fragments in the agarose gel. In order to visualize DNA damage, 100 nuclei per slide were examined at 400x magnification. The results were expressed as the percent of DNA in the tail, "tail intensity". The experiment was performed in duplicate and repeated three times.

\section{Determination of apoptotic genes by RT-PCR}

V79 cells were treated with DMSA/Ag ${ }_{2} \mathrm{~S}$ QDs at concentrations of $125,250,500$, and $1000 \mu \mathrm{g} / \mathrm{mL}$ in 6-well plates for $24 \mathrm{~h}$. After the completion of the exposure time, total RNA was extracted with a Qiagen RNeasy Plus Mini Kit (Valencia, CA, USA) according to the manufacturer's protocol. The RNA content was estimated using a Nanodrop 8000 spectrophotometer (Thermo Fisher Scientific, Wilmington, DE, USA), and the integrity of RNA was visualized on $1 \%$ agarose gel using a gel documentation system (Thermo Fisher Scientific, Wilmington, DE, USA). First-strand cDNA was synthesized using an $\mathrm{RT}^{2}$ First Strand Kit (Qiagen, Valencia, CA, USA) according to the manufacturer's instructions. Quantitative RT-PCR was performed by QuantiTect SYBR Green PCR kit (Qiagen) using a Corbett RotorGene Sequence Detection System (Thermo Fisher Scientific, Wilmington, DE, USA). Two microliters of template cDNA was added to the final volume of $20 \mu \mathrm{L}$ of reaction mixture. The RT-PCR cycle parameters included $10 \mathrm{~min}$ at $95^{\circ} \mathrm{C}$ followed by 40 cycles involving denaturation at $95^{\circ} \mathrm{C}$ for $15 \mathrm{~s}$, annealing at $60^{\circ} \mathrm{C}$ for $20 \mathrm{~s}$, and elongation at $72^{\circ} \mathrm{C}$ for $20 \mathrm{~s}$. The sequences of the specific sets of primer for $p 53$, caspase-3, caspase-9, Bax, Bcl2, and survivin utilized in the present investigation are given in our previous study. ${ }^{45}$
Expressions of selected genes were normalized to the gapdh gene and then used as controls. The experiment was performed in duplicate and repeated three times.

\section{Statistical analysis}

Statistical analysis was performed with SPSS for Windows 20.0 for the alkaline comet assay. Differences between the means of data were compared by one-way variance analysis and post hoc analysis of group differences by the least significant difference test. The RT-PCR array was analyzed by t-test. Significance in the RT-PCR array was determined based on the fold change from the control $\Delta \Delta C$ t value. The results were expressed as the mean \pm standard deviation. A p value of less than 0.05 was considered statistically significant.

\section{RESULTS}

\section{Cytotoxicity of DMSA/Ag ${ }_{2} S$ QDs by MTT assay}

The V79 cells were treated with DMSA/Ag 2 QDs and free DMSA to determine the cytotoxicity of the QDs itself and the coating material over a wide range of concentrations between 0 and $2000 \mu \mathrm{g} / \mathrm{mL}$ for $24 \mathrm{~h}$. The cytotoxicity was then evaluated by MTT assay. The data provided in Figure $2 \mathrm{a}$

(a)

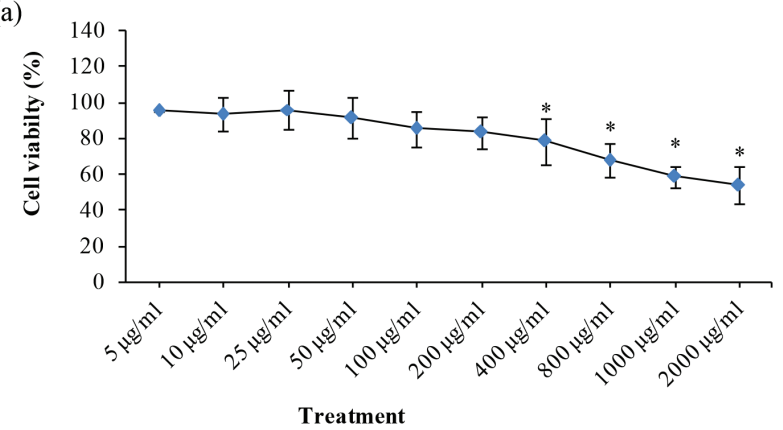

(b)

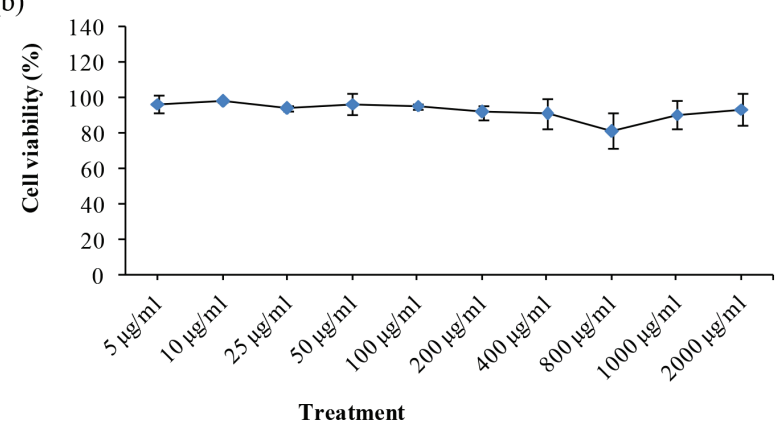

Figure 2. Influence of DMSA/Ag $\mathrm{S}$ QDs (a) and free DMSA solutions (b) on viability of V79 cells using the MTT assay. Cell viability was plotted as percent of negative control (assuming data obtained from untreated cells as $100 \%)$. Results were given as the mean \pm standard deviation. Differences between the means of data were compared by one-way analysis of variance and post hoc analysis of group differences by least significant difference test. * Significant difference as compared to the negative control $(p<0.05)$. Negative control (1\% PBS), positive control $\left(50 \mu \mathrm{M} \mathrm{H}_{2} \mathrm{O}_{2}\right.$ ). The cell viability of the positive control was $48.5 \%$

$\mathrm{Ag}_{2} \mathrm{~S}$ : Silver sulfide, QDs: Quantum dots, DMSA: Meso-2,3-dimercaptosuccinic acid MTT: 3-(4,5-dimethylthiazol-2-yl)-2,5-diphenyltetrazolium bromide, PBS: Phosphate buffered saline 
exhibited no significant cytotoxicity between 5 and $200 \mu \mathrm{g} / \mathrm{mL}$ and a concentration-dependent decline in the survival of cells exposed to DMSA/Ag $2 \mathrm{~S}$ QDs at higher concentrations (400$2000 \mu \mathrm{g} / \mathrm{mL}$ ) when compared to the untreated control. IC $C_{50}$ of DMSA/Ag $2 \mathrm{~S}$ QDs was not determined at these concentrations. Cell viability was $54.0 \pm 4.8 \%$ at the highest doses $(2000 \mu \mathrm{g} / \mathrm{mL})$. As shown in Figure $2 \mathrm{~b}$, free DMSA did not cause any significant cytotoxicity in V79 cells within the same concentration range.

\section{Cytotoxicity of DMSA/Ag $S$ QDs by NRU assay}

The results for cytotoxicity as evaluated by NRU cell viability indicated no significant cytotoxicity at concentrations between 5 and $400 \mu \mathrm{g} / \mathrm{mL}$ when compared to the untreated control, but a clear dose-dependent toxicity at higher concentrations (800$2000 \mu \mathrm{g} / \mathrm{mL}$ ) was observed (Figure $3 a$ ). $I C_{50}$ of $\mathrm{DMSA} / \mathrm{Ag}_{2} \mathrm{~S}$ was not determined. Cell viability was $65.7 \pm 4.1 \%$ at the highest dose $(2000 \mu \mathrm{g} / \mathrm{mL})$ of $\mathrm{Ag}_{2} \mathrm{~S}$ QDs. Similar to the results obtained from the MTT assay, DMSA alone did not show cytotoxicity in V79 cells with the same studied doses (Figure $3 \mathrm{~b}$ ).

(a)

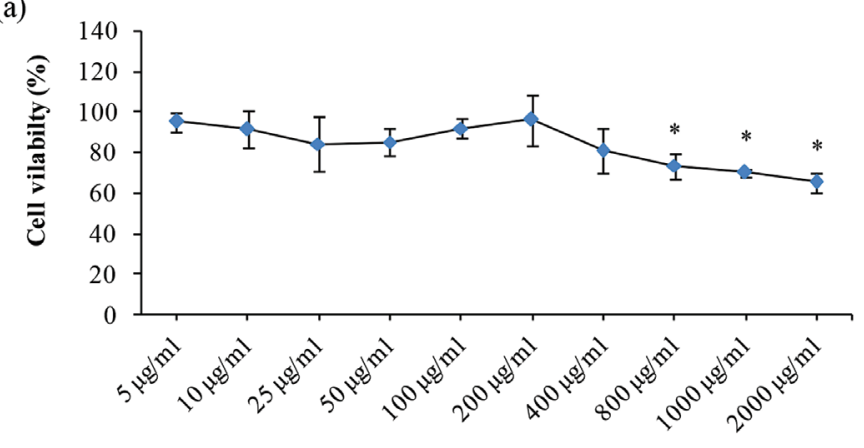

Treatment

(b)

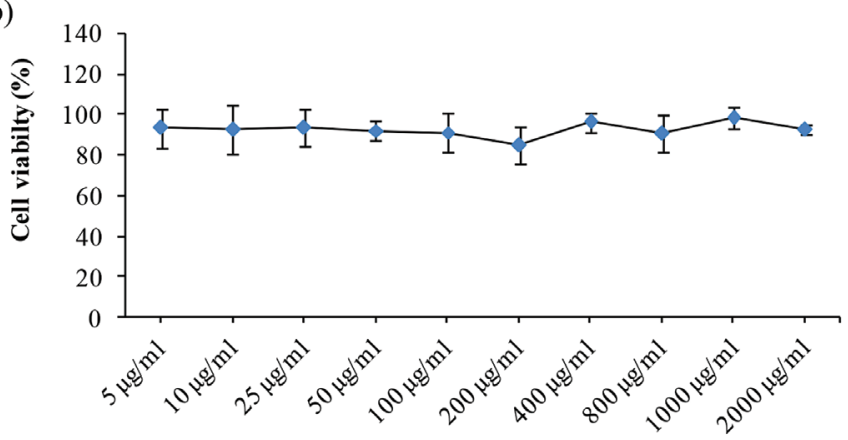

Treatment

Figure 3. Effects of DMSA/Ag 2 Q QDs (a) and DMSA solutions (b) on viability of V79 cells using the NRU assay. Cell viability was plotted as percent of negative control (assuming data obtained from untreated cells as $100 \%$ ). Results were given as the mean \pm standard deviation. Differences between the means of data were compared by one-way analysis of variance and post hoc analysis of group differences by least significant difference test * Significant difference as compared to the negative control $(p<0.05)$. Negative control (1\% PBS), positive control $\left(50 \mu \mathrm{M} \mathrm{H}_{2} \mathrm{O}_{2}\right)$. The cell viability of the positive control was $53.6 \%$

$\mathrm{Ag}_{2} \mathrm{~S}$ : Silver sulfide, QDs: Quantum dots, DMSA: Meso-2,3-dimercaptosuccinic acid, NRU: Neutral red uptake, PBS: Phosphate buffered saline

\section{Genotoxicity of DMSA/Ag $\mathrm{S} Q D$ s}

Genotoxicity of these QDs was evaluated by comet assay (Figures 4 and 5). DNA damage, expressed as "DNA tail intensity" in V79 cells, is presented in Figure 4. No significant DNA damage was observed, since DMSA/Ag $\mathrm{S}$ QDs treatments $(5-2000 \mu \mathrm{g} / \mathrm{mL})$ for $24 \mathrm{~h}$ did not change DNA tail intensity in V79 cells (Figure 5 ).

\section{Effects of DMSA/Ag $g_{2} \mathrm{~S} Q D$ s on the expressions of apoptotic} genes

The mRNA expression levels of p53, caspase-3, caspase-9, Bax, Bcl-2, and survivin genes (apoptotic markers) in V79 cells treated with DMSA/Ag $\mathrm{S}$ QDs at concentrations of 125,250 , 500 , and $1000 \mu \mathrm{g} / \mathrm{mL}$ for $24 \mathrm{~h}$ was analyzed by RT-PCR assay.

The results demonstrated that the mRNA expression levels of apoptotic genes $p 53$, caspase-3, caspase-9, and Bax were upregulated, while the expressions of anti-apoptotic genes $\mathrm{BCl}$ 2 and survivin were down-regulated in V79 cells treated with the highest concentration of DMSA $/ \mathrm{Ag}_{2} \mathrm{~S}$ QDs $(1000 \mu \mathrm{g} / \mathrm{mL})$ ( $p<0.05)$ (Figure 6). No significant changes were observed in lower concentrations. The ratio of $\mathrm{Bax} / \mathrm{Bcl}-2$ gene expression levels in the cells treated with $\mathrm{DMSA} / \mathrm{Ag}_{2} \mathrm{~S}$ QDs (Figure 7) suggests that these two genes may play a significant role in the pathway of DMSA/Ag $\mathrm{S}$ QDs via apoptosis.

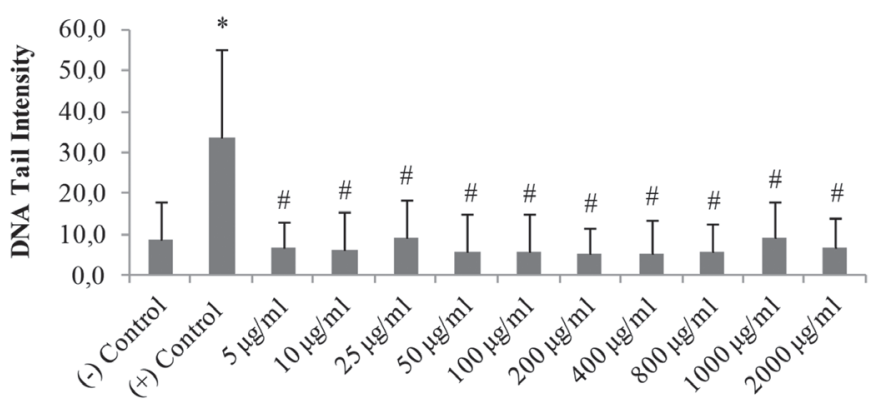

Tretament

Figure 4. DNA damage expressed as tail intensity in the V79 cells treated with DMSA $/ \mathrm{Ag}_{2} \mathrm{~S}$ QDs. Results were given as the mean \pm standard deviation. Differences between the means of data were compared by oneway analysis of variance and post hoc analysis of group differences by least significant difference test. ${ }^{*} p<0.05$, significantly different from the negative control. ${ }^{*} \mathrm{p}<0.05$, significantly different from the positive control. Negative control (1\% PBS), positive control ( $50 \mu \mathrm{M} \mathrm{H}_{2} \mathrm{O}_{2}$ )

$\mathrm{Ag}_{2} \mathrm{~S}$ : Silver sulfide, QDs: Quantum dots, DMSA: Meso-2,3-dimercaptosuccinic acid, PBS: Phosphate buffered saline
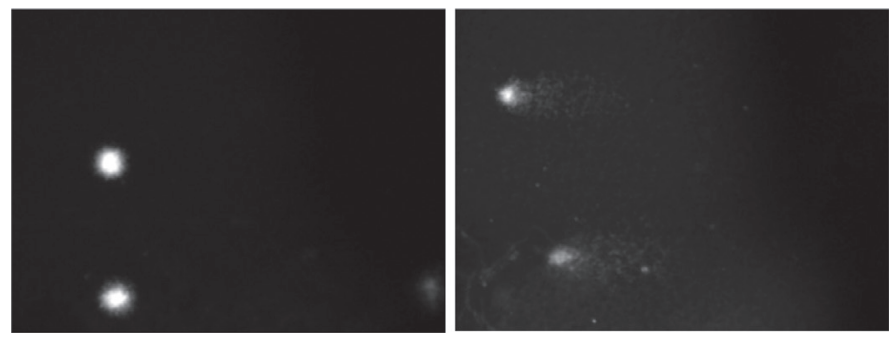

Figure 5. The comet microscopic images of V79 cells. (a) Undamaged cells treated with DMSA/ $\mathrm{Ag}_{2} \mathrm{~S}$ QDs and (b) damaged cells treated with $50 \mu \mathrm{M}$ $\mathrm{H}_{2} \mathrm{O}_{2}$ were examined at $400 \times$ magnification

$\mathrm{Ag}_{2} \mathrm{~S}$ : Silver sulfide, QDs: Quantum dots, DMSA: Meso-2,3-dimercaptosuccinic acid 


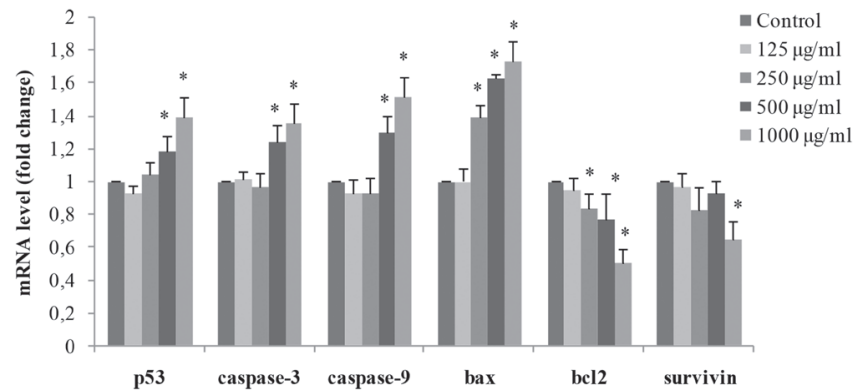

Figure 6. DMSA/Ag $\mathrm{S}$ QDs-induced apoptosis in V79 cells. Cells were exposed to DMSA/Ag $S$ QDs at the dosages of $0,125,250,500$, and 1000 $\mu \mathrm{g} / \mathrm{mL}$ for $24 \mathrm{~h}$. At the end of exposure, mRNA levels of the $p 53$, caspase-3, caspase-9, Bax, Bcl2, and survivin genes were measured as described in the Materials and Methods. Results were given as the mean \pm standard deviation. The real-time polymerase chain reaction (RT PCR) arrays were analyzed by t-test. Significance in the PCR array was determined based on fold change from the control $\triangle \Delta C t$ value. ${ }^{*}$ Significant difference as compared to the negative control ( $p<0.05)$. Negative control (1\% PBS)

$\mathrm{Ag}_{2} \mathrm{~S}$ : Silver sulfide, QDs: Quantum dots, DMSA: Meso-2,3-dimercaptosuccinic acid, PCR: Polymerase chain reaction, PBS: Phosphate buffered saline

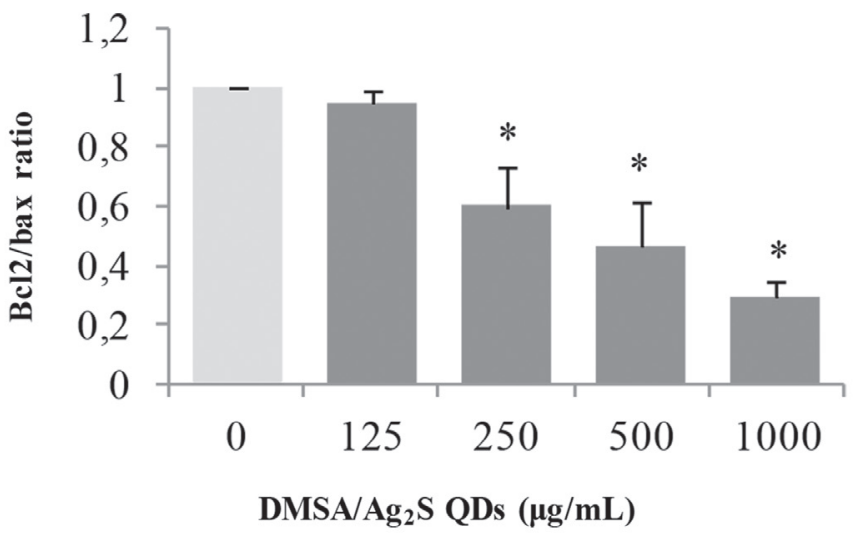

Figure 7. The ratio of $B c / 2 / B a x$ mRNA in V79 cells. Cells were exposed to DMSA/Ag 2 S QDs at the dosages of $0,125,250,500$, and $1000 \mu \mathrm{g} / \mathrm{mL}$ for 24 h. ${ }^{*}$ Significant difference as compared to the negative control $(p<0.05)$. Negative control (1\% PBS)

$\mathrm{Ag}_{2} \mathrm{~S}$ : Silver sulfide, QDs: Quantum dots, DMSA: Meso-2,3-dimercaptosuccinic acid, PBS: Phosphate buffered saline

\section{DISCUSSION}

There has been increasing concern regarding the toxicity of QDs, but further effort is needed to make them safe for biomedical application. ${ }^{46}$ The toxic effects of different QDs have already been investigated in vitro ${ }^{34,47-51}$ as well as in vivo. ${ }^{50,52}$ QDs are suggested to be cytotoxic and/or to change gene expression ${ }^{53}$ and the cores and coatings of QDs may be responsible for their toxicity. ${ }^{54} \mathrm{Ag}_{2} \mathrm{~S} \mathrm{QDs}$ were considered to be much less toxic than QDs such as PbSe, PbS, and CdHgTe QDs, because of the lack of toxic metals, such as $\mathrm{Pb}, \mathrm{Hg}$, and $\mathrm{Cd} . \mathrm{Ag}_{2} \mathrm{~S} \mathrm{QD}$ s are promising fluorescent probes with both bright photoluminescence in the NIR and high biocompatibility, making them highly selective in in vitro targeting and imaging of different cell lines. ${ }^{55} \mathrm{Ag}_{2} \mathrm{~S}$ QDs are reported to have no significant effects in altering cell viability, triggering apoptosis or necrosis, forming reactive oxygen species (ROS), or causing DNA damage in in vitro toxicity studies. ${ }^{38,55}$

In recent years NP applications towards cell apoptosis have been an increasing focus. Unfortunately, such wide use may pose an unwanted threat to human health and so there is a need for a precise analysis of NP cytotoxicity in living cells. An understanding of the exact role their properties (size, shapes, surface charges, dispersion/agglomeration status) play in the decision about NP safety and suitability is necessary. In addition, some aspects of surface modification may be able to reduce the bioreactivity of NPs, thus alleviating their toxicities in certain circumstances. This may provide a way to design even more effective particles of minimum undesired toxicity.

In the present study, it was aimed to evaluate the cytotoxic, genotoxic, and apoptotic potentials of DMSA/Ag $2 \mathrm{~S}$ QDs in the V79 cell line. We performed MTT and NRU cytotoxicity assays, since they are generally used tests to determine the cytotoxicity of NPs in different cell lines. ${ }^{56-59}$ These assays differ depending on the different mechanisms leading to cell death. Therefore, it is important to check nanotoxicity with different protocols. The $\mathrm{NRU}$ assay is a colorimetric assay measuring the uptake of dye by viable cells and its accumulation in functional lysosomes, while the MTT assay is based on the enzymatic conversion of MTT in the mitochondria. ${ }^{60}$ The lung fibroblast V79 cell line was used in our experiment. The rationale for choosing this cell line is that it has been widely studied in many nanocytotoxicity and nanogenotoxicity assays, because of its excellent properties in colony formation and also its high sensitivity to many chemicals. ${ }^{61-65}$ The question of dose becomes important when comparing studies and when developing predictive models of nanoparticle toxicity. This is very important when comparing in vitro and in vivo studies, where physicochemical parameters make simple comparisons difficult. Consistent with the previous studies, ${ }^{61-65} 24 \mathrm{~h}$ of exposure was selected to be the optimal time for measurements of the effects of NPs on cell viability. It has been reported that rather high concentrations of $\mathrm{NM}$ solutions are used in in vitro studies ( 30 to $400 \mu \mathrm{g} / \mathrm{mL}$ ) in the literature. ${ }^{66}$ There are no cytotoxicity studies for the doses of DMSA/Ag 2 in V79 cells, and therefore we used wide concentration ranges of DMSA $/ \mathrm{Ag}_{2} \mathrm{~S}$ QDs $(0-2000 \mu \mathrm{g} / \mathrm{mL})$.

In our study, DMSA/Ag $\mathrm{S}$ QDs reduced cell viability above $400 \mu \mathrm{g} / \mathrm{mL}$ using the MTT assay and above $800 \mu \mathrm{g} / \mathrm{mL}$ using the NRU assay, indicating dose-dependent toxicity in both assays. MTT seems to be more sensitive in detecting changes in viability at low concentrations. ${ }^{67}$ In both the MTT and NRU assays, DMSA alone did not significantly induce cell death in the same concentration range between 5 and $2000 \mu \mathrm{g} / \mathrm{mL}$. It seems that the coating material may prevent cytotoxicity. The biocompatibility of DMSA coupled with the extremely low solubility of $\mathrm{Ag}_{2} \mathrm{~S}$ core preventing release of high concentration of $\mathrm{Ag}^{+}$from the core accounts for the biocompatibility of DMSA/ $\mathrm{Ag}_{2} \mathrm{~S}$ at least in short-term exposure. Munari et al..$^{54}$ reported that methyl polyethylene glycol-coated $\mathrm{Ag}_{2} \mathrm{~S}(0.01-50 \mu \mathrm{g} / \mathrm{mL})$ showed neither genotoxic nor cytotoxic effects.

It is important to use the appropriate method to measure the cytotoxicity of interest without false-negative or -positive misconstruction of the result. The MTT and NRU assays 
may sometimes suffer from severe interferences caused by interaction of metallic NPs with assay reagents. Serious consideration is critical to obtain reliable and realistic data. ${ }^{68}$ Interference with analytical techniques should be considered in terms of NP intrinsic fluorescence/absorbance and interactions between NPs and assay components. Due to the unique physicochemical properties and increased reactivity of NPs, there is a high potential for these materials to interfere with spectrophotometric and spectrofluorimetric assays. NPs can bind to proteins and dyes and alter their structure and/or function, and it is probable that this process occurs in common toxicity assays. Aluminum NPs showed a strong interaction with the MTT dye, causing significant misreading of the cell viability data. ${ }^{69,70}$ Some NPs (iron/graphite magnetic particles, super-paramagnetic magnetite/silica NPs, bare and PEGylated silica NPs, and magnetic composites magnetite/FAU zeolite) in culture medium in the absence of cells have the same wavelength used in MTT assays at $525 \mathrm{~nm}$. This absorbance increases with the NP concentration and can greatly interfere with MTT assay results. ${ }^{71}$ However, in our study DMSA/ $\mathrm{Ag}_{2} \mathrm{~S}$ QDs had the emission maximum at $870 \mathrm{~nm}$ with broad absorption up to $800 \mathrm{~nm}$. In the MTT and NRU assays the absorbance was $570 \mathrm{~nm}$ and $540 \mathrm{~nm}$, respectively. DMSA/Ag $\mathrm{S}$ QDs appear not to interact with MTT reagent, and therefore there is no absorbance interference.

The comet assay is a sensitive method to detect DNA strand breaks as well as oxidatively damaged DNA at single cell level. The effect of NPs to cause DNA damage is an important issue in mutations and carcinogenesis. Oxidative stress but also other mechanisms may also be involved in the genotoxicity of NPs, including direct NP-DNA interactions and disturbance of the mitotic spindle and its components. ${ }^{72,73}$ In our study, DMSA/Ag 2 QD treatments $(5-2000 \mu \mathrm{g} / \mathrm{mL})$ for $24 \mathrm{~h}$ did not increase DNA tail intensity in V79 cells, which may indicate no genotoxic effects. The biocompatibility of $\mathrm{Ag}_{2} \mathrm{~S}$ QDs in the mouse fibroblast L929 cell line, including cell proliferation, cell apoptosis/necrosis, production of ROS, and DNA damage using the comet assay, was investigated by Zhang et al. ${ }^{55}$ in a study comparable with ours. They used different $\mathrm{Ag}_{2} \mathrm{~S}$ QDs with different targeting ligands including dihydrolipoic acid and poly(ethylene glycol) (PEG). The proliferation, ROS production, and DNA damage of L929 cells treated with 6.25, 12.5, 25, 50, and $100 \mu \mathrm{g} / \mathrm{mL} \mathrm{Ag} \mathrm{S}$ QDs for $72 \mathrm{~h}$ were not significantly different from those of the negative control. The results presenting negligible toxicity of $\mathrm{Ag}_{2} \mathrm{~S}$ QDs at concentrations up to $100 \mu \mathrm{g} / \mathrm{mL}$ show that $\mathrm{Ag}_{2} \mathrm{~S}$ QDs are highly biocompatible in their study. $\mathrm{Ag}_{2} \mathrm{~S}$ QDs did not interfere with cell proliferation, which makes them suitable for use in the labeling of in vitro systems. These observations illustrated the biocompatible nature of $\mathrm{Ag}_{2} \mathrm{~S}$ without side effects on cell proliferation. Previous studies confirmed that some QDs have high biocompatibilities and low toxicities. ${ }^{74-76}$ The coating material may be suggested to reduce cytotoxicity. Consistent with our study, Jebali et al. ${ }^{77}$ (2014) reported that free fatty acids-coated Ag NPs had less toxicity, higher uptake, and less ROS generation than unbound Ag NPs. Hocaoglu et al. ${ }^{78}$ showed the biocompatibility of 2-mercaptopropionic acid/ $\mathrm{Ag}_{2} \mathrm{~S}$ QDs even at the highest concentration of $600 \mu \mathrm{g} / \mathrm{mL}$ in $\mathrm{NIH} / 3 \mathrm{~T} 3$ cells after $24 \mathrm{~h}$ incubation using the XTT assay. Hocaoglu et al. ${ }^{38}$ also showed that DMSA/Ag 2 QDs did not reduce cell viability up to $200 \mu \mathrm{g} / \mathrm{mL}$ in HeLa cells and showed only $20 \%$ reduction in cell viability of $3 \mathrm{~T} 3 \mathrm{NIH}$ cells over $24 \mathrm{~h}$.

Apoptosis, via extracellular or intracellular signals, triggers the onset of a signaling cascade with characteristic biochemical and cytological signatures with nuclear condensation and DNA fragmentation. ${ }^{79}$ Several genes are known to sense DNA damage and apoptosis. In the presence of DNA damage or cellular stress, the p53 protein triggers cell-cycle arrest to provide time for the damage to be repaired or for self-mediated apoptosis. $^{16}$ The p53 gene maintains genomic stability via activating cell cycle checkpoints, DNA repair, and apoptosis. ${ }^{80}$ Survivin, described as an inhibitor of caspase- 9 and a member of the family of inhibitors of apoptotic proteins, functions as a key regulator of mitosis and programmed cell death. Survivin has been reported to play an important role in both cell proliferation and apoptosis. ${ }^{17}$ Initially, survivin gene expression is transcriptionally repressed by wild-type p53 and can be deregulated in cancer by several mechanisms, including gene amplification, hypomethylation, increased promoter activity, and loss of p53 function. ${ }^{81}$ Downregulation of survivin may cause a cell-cycle defect that leads to apoptosis. The Bax and Bcl2 proteins regulate apoptotic pathways. The $\mathrm{Bcl}-2$ protein has an antiapoptotic activity, while Bax has a pro-apoptotic effect. ${ }^{18}$ The ratio of $\mathrm{Bax} / \mathrm{Bcl}-2$ proteins represents a cell death switch, which determines the life or death of cells in response to an apoptotic stimulus; an increased $\mathrm{Bax} / \mathrm{Bcl}-2$ ratio decreases the cellular resistance to apoptotic stimuli, leading to apoptosis. It is crucial in mitochondrial outer-membrane permeabilization and the release of cytochrome $\mathrm{C}$ in the cytosol.19,82,83 Moreover, destabilization of mitochondrial integrity by apoptotic stimuli precedes activation of caspases, leading to apoptosis. ${ }^{84,85}$ Caspases, essential in cellular DNA damage and apoptosis, are known to play a vital role in both the initiation and execution of apoptosis in many cells. ${ }^{86}$

The transcriptional data on modulation of p53 and $\mathrm{Bax} / \mathrm{Bcl}-2$ ratio and release of caspases have strengthened the role of DMSA/Ag 2 S QDs in inducing mitochondrial dependent apoptotic pathways. The main intrinsic pathway is characterized by mitochondrial dysfunction, with the release of cytochrome c activation of caspase-9, and subsequently of caspase-3 enzyme. ${ }^{87,88}$ Typically, p53 is activated when DNA damage occurs or cells are stressed; p53 is then translocated to the nucleus, where it can induce pro-apoptotic gene expression on the mitochondrial membrane, activate the effector caspases, and accelerate cell death. ${ }^{88,89}$ Survivin inhibition induces the activation of caspase- 3 and caspase-9 enzymes. ${ }^{89-91}$ Taken together, up-regulation of p53 and down-regulation of survivin lead to activation of pro-apoptotic members of the Bcl-2 family. This includes Bax, inducing permeabilization of the outer mitochondrial membrane, which releases soluble proteins from the intermembrane space into the cytosol, where they promote caspase activation. ${ }^{85,92}$ The expression of antiapototic protein $\mathrm{Bcl}-2$ was significantly lower, and the expression of proapoptotic protein Bax was significantly higher in cells exposed 
DMSA/Ag 2 S QDs, suggesting that these genes could be excellent molecular biomarkers to assess the apoptotic response of NPs. In our study, no significant changes in mRNA expression levels were observed between 125 and $500 \mu \mathrm{g} / \mathrm{mL}$, but a clear effect on apoptotic/antiapoptotic gene expression levels was detected at the dose of $1000 \mu \mathrm{g} / \mathrm{mL}$. The mRNA expression levels of apoptotic genes p53, caspase-3, caspase-9, and Bax were up-regulated, while the expressions of anti-apoptotic genes $\mathrm{Bcl}-2$ and survivin were down-regulated in V79 cells treated with the highest concentration of $1000 \mu \mathrm{g} / \mathrm{mL}$ of DMSA/Ag $\mathrm{S}$ QDs. The results show that the related gene expression levels may change only at a very high cytotoxic dose, indicating that DMSA/Ag 2 S QDs may lead to cell death via apoptotic pathways at very high doses.

\section{CONCLUSIONS}

In our study, the potential cytotoxic, genotoxic, and apoptotic effects of DMSA/Ag 2 S QDs in vitro were evaluated. $\mathrm{Ag}_{2} \mathrm{~S}$ QDs coated with DMSA had high biocompatibility and low toxicity, since heavy metal-related cytotoxicity was eliminated by using quite a biocompatible and insoluble $\mathrm{Ag}_{2} \mathrm{~S}$ semiconductor core.

Our data show that DMSA/Ag $S$ QDs have neither cytotoxic nor genotoxic effects in V79 cells in medically relevant doses. They may induce apoptosis via p53, survivin, Bax/Bcl-2, and caspase pathways at high dose. The underlying mechanisms of DMSA/ $\mathrm{Ag}_{2} \mathrm{~S}$ QDs should be confirmed by additional experiments in order to prove our results. Further investigation is needed to determine whether in vivo exposure consequences may exist for DMSA/Ag $\mathrm{S}$ QDs application and also to make QDs safe for widespread use.

\section{ACKNOWLEDGEMENTS}

This work was supported by TÜBITAK (Project Number: 114S861).

Conflict of Interest: No conflict of interest was declared by the authors.

\section{REFERENCES}

1. Rothenfluh DA, Bermudez H, O'Neil CP, Hubbell JA. Biofunctional polymer nanoparticles for intra-articular targeting and retention in cartilage. Nat Mater. 2008;7:248-254.

2. Kostarelos K, Bianco A, Prato M. Promises, facts and challenges for carbon nanotubes in imaging and therapeutics. Nat Nanotechnol. 2009; $4: 627-633$.

3. Michalet X, Pinaud FF, Bentolila LA, Tsay JM, Doose S, Li JJ, Sundaresan G, Wu AM, Gambhir SS, Weiss S. Quantum dots for live cells, in vivo imaging, and diagnostics. Science. 2005;307:538-544.

4. Chen Z, Tabakman SM, Goodwin AP, Kattah MG, Daranciang D, Wang X, Zhang G, Li X, Liu Z, Utz PJ, Jiang K, Fan S, Dai H. Protein microarrays with carbon nanotubes as multicolor Raman labels. Nat Biotechnol. 2008;26:1285-1292.

5. Qian X, Peng XH, Ansari DO, Yin-Goen Q, Chen GZ, Shin DM, Yang L, Young AN, Wang MD, Nie S. In vivo tumor targeting and spectroscopic detection with surface-enhanced Raman nanoparticle tags. Nat Biotechnol. 2008;26:83-90.

6. He Y, Fan C, Lee ST. Silicon nanostructures for bioapplications. Nano Today. 2010;5:282-295.

7. McAuliffe ME, Perry MJ. Are nanoparticles potential male reproductive toxicants? A literature review. Nanotoxicology. 2007;1:204-210.

8. Nel A, Xia T, Mädler L, Li N. Toxic potential of materials at the nanolevel. Science. 2006;311:622-627.

9. Oberdörster G, Oberdörster E, Oberdörster J. Nanotoxicology: An emerging discipline evolving from studies of ultrafine particles. Environ Health Perspect. 2005;113:823-839.

10. Singh SK, Kulkarni PP, Dash D. Biomedical Applications of Nanomaterials: An Overview. Bio Nanotechnology: A Revolution in Food. Biomedical and Health Sciences. 2013:1-32.

11. Chan WC, Maxwell DJ, Gao X, Bailey RE, Han M, Nie S. Luminescent quantum dots for multiplexed biological detection and imaging. Curr Opin Biotechnol. 2002;13:40-46.

12. Klimov VI. Spectral and dynamical properties of multiexcitons in semiconductor nanocrystals. Annu Rev Phys Chem. 2007;58:635-673.

13. Murphy CJ, Coffer JL. Quantum dots: A primer. Appl Spectrosc. 2002;56:16-27.

14. Bruchez Jr M, Moronne M, Gin P, Weiss S, Alivisatos AP. Semiconductor nanocrystals as fluorescent biological labels. Science. 1998;281:20132016.

15. Chan WCW, Nie S. Quantum dot bioconjugates for ultrasensitive nonisotopic detection. Science. 1998;281:2016-2018.

16. Medintz I. Universal tools for biomolecular attachment to surfaces. Nat Mater. 2006;5:842.

17. Wagner MK, Li F, Li J, Li XF, Le XC. Use of quantum dots in the development of assays for cancer biomarkers. Anal Bioanal Chem. 2010;397:3213-3224.

18. Mattoussi H, Palui G, Na HB. Luminescent quantum dots as platforms for probing in vitro and in vivo biological processes. Adv Drug Deliv Rev.2012;64:138-166.

19. Frigerio C, Ribeiro DS, Rodrigues SS, Abreu VL, Barbosa JA, Prior JA, Marques KL, Santos JL. Application of quantum dots as analytical tools in automated chemical analysis: A review. Anal Chim Acta. 2012;735:9-22.

20. Frasco MF, Chaniotakis N. Bioconjugated quantum dots as fluorescent probes for bioanalytical applications. Anal Bioanal Chem. 2010;396:229240.

21. Wu X, Liu H, Liu J, Haley KN, Treadway JA, Larson JP, Ge N, Peale F, Bruchez MP. Immunofluorescent labeling of cancer marker Her2 and other cellular targets with semiconductor quantum dots. Nat Biotechnol. 2003;21:41-46.

22. Algar WR, Prasuhn DE, Stewart MH, Jennings TL, Blanco-Canosa JB, Dawson PE, Medintz IL. The controlled display of biomolecules on nanoparticles: a challenge suited to bioorthogonal chemistry. Bioconjug Chem. 2011;22:825-858.

23. Rosenthal SJ, Chang JC, Kovtun O, McBride JR, Tomlinson ID. Biocompatible quantum dots for biological applications. Chem Biol. 2011;18:10-24

24. Petryayeva E, Algar WR, Medintz IL. Quantum dots in bioanalysis: A review of applications across various platforms for fluorescence spectroscopy and imaging. Appl Spectrosc. 2013;67:215-252. 
25. Alivisatos AP. Semiconductor clusters, nanocrystals, and quantum dots. Science. 1996;271:933-937.

26. Weller H. Quantum size colloids: From size-dependent properties of discrete particles to self-organized superstructures. Curr Opin Colloid Interface Sci. 1998;3:194-199.

27. Dabbousi BO, Rodriguez-Viejo J, Mikulec FV, Heine JR, Mattoussi H, Ober R, Jensen KF, Bawendi MG. (CdSe)ZnS core-shell quantum dots: Synthesis and characterization of a size series of highly luminescent nanocrystallites. J Phys Chem B. 1997;101:9463-9475.

28. Hines MA, Guyot-Sionnest P. Synthesis and characterization of strongly luminescing ZnS-capped CdSe nanocrystals. J Phy Chem. 1996;100:468471.

29. Hardman R. A toxicologic review of quantum dots: Toxicity depends on physicochemical and environmental factors. Environ Health Perspect. 2006;114:165-172.

30. Kim S, Lim YT, Soltesz EG, De Grand AM, Lee J, Nakayama A, Parker JA, Mihaljevic T, Laurence RG, Dor DM, Cohn LH, Bawendi MG, Frangioni JV. Near-infrared fluorescent type II quantum dots for sentinel lymph node mapping. Nat Biotechnol. 2004;22:93-97.

31. Chan WH, Shiao NH, Lu PZ. CdSe quantum dots induce apoptosis in human neuroblastoma cells via mitochondrial-dependent pathways and inhibition of survival signals. Toxicol Let. 2006;167:191-200.

32. Chen N, He Y, Su Y, Li X, Huang Q, Wang H, Zhang X, Tai R, Fan C. The cytotoxicity of cadmium-based quantum dots. Biomaterials. 2012;33:1238-1244.

33. Cho SJ, Maysinger D, Jain M, Röder B, Hackbarth S, Winnik FM. Longterm exposure to $\mathrm{CdTe}$ quantum dots causes functional impairments in live cells. Langmuir. 2007;23:1974-1980.

34. Kirchner C, Liedl T, Kudera S, Pellegrino T, Muñoz Javier A, Gaub HE, Stölzle S, Fertig N, Parak WJ. Cytotoxicity of colloidal CdSe and CdSe/ ZnS nanoparticles. Nano Lett. 2005;5:331-338.

35. Li KG, Chen JT, Bai SS, Wen X, Song SY, Yu Q, Li J, Wang YQ. Intracellular oxidative stress and cadmium ions release induce cytotoxicity of unmodified cadmium sulfide quantum dots. Toxicol In Vitro. 2009;23:10071013.

36. Male KB, Lachance B, Hrapovic S, Sunahara G, Luong JHT. Assessment of cytotoxicity of quantum dots and gold nanoparticles using cell-based impedance spectroscopy. Anal Chem. 2008;80:5487-5493.

37. Gao J, Chen X, Cheng Z. Near-infrared quantum dots as optical probes for tumor imaging. Curr Top Med Chem. 2010;10:1147-1157.

38. Hocaoglu I, Demir F, Birer O, Kiraz A, Sevrin C, Grandfils C, Acar HY. Emission tunable, cyto/hemocompatible, near-IR-emitting Ag2S quantum dots by aqueous decomposition of DMSA. Nanoscale. 2014;6:11921-11931.

39. Rao BS, Shanbhoge R, Rao BN, Adiga SK, Upadhya D, Aithal BK, Kumar MR. Preventive efficacy of hydroalcoholic extract of Cymbopogon citratus against radiation-induced DNA damage on V79 cells and free radical scavenging ability against radicals generated in vitro. Hum Exp Toxicol. 2009;28:195-202.

40. Mosmann T. Rapid colorimetric assay for cellular growth and survival: Application to proliferation and cytotoxicity assays. J Immunol Methods. 1983;65:55-63.

41. Hansen MB, Nielsen SE, Berg K. Re-examination and further development of a precise and rapid dye method for measuring cell growth/cell kill. J Immunol Methods. 1989;119:203-210.
42. Kuźma Ł, Wysokińska H, Rózalski M, Krajewska U, Kisiel W. An unusual taxodione derivative from hairy roots of Salvia austriaca. Fitoterapia. 2012;83:770-773.

43. Di Virgilio AL, Iwami K, Wätjen W, Kahl R, Degen GH. Genotoxicity of the isoflavones genistein, daidzein and equol in V79 cells. Toxicol Lett. 2004; 151:1511-1562.

44. Saquib Q, Al-Khedhairy AA, Siddiqui MA, Abou-Tarboush FM, Azam A, Musarrat J. Titanium dioxide nanoparticles induced cytotoxicity, oxidative stress and DNA damage in human amnion epithelial (WISH) cells. Toxicol In Vitro. 2012;26:351-561.

45. Ahamed M, Akhtar MJ, Siddiqui MA, Ahmad J, Musarrat J, Al-Khedhairy AA, AlSalhi MS, Alrokayan SA. Oxidative stress mediated apoptosis induced by nickel ferrite nanoparticles in cultured A549 cells. Toxicology. 2011;283:101-108.

46. Winnik FM, Maysinger D. Quantum dot cytotoxicity and ways to reduce it. Acc Chem Res. 2013;46:672-680.

47. Manshian BB, Soenen SJ, Brown A, Hondow N, Wills J, Jenkins GJ, Doak $\mathrm{SH}$. Genotoxic capacity of $\mathrm{Cd} / \mathrm{Se}$ semiconductor quantum dots with differing surface chemistries. Mutagenesis. 2016;31:97-106.

48. Smith WE, Brownell J, White CC, Afsharinejad Z, Tsai J, Hu X, Polyak SJ, Gao X, Kavanagh TJ, Eaton DL. In vitro toxicity assessment of amphiphillic polymer-coated CdSe/ZnS quantum dots in two human liver cell models. ACS Nano. 2012;6:9475-9484.

49. Smulders S, Luyts K, Brabants G, Golanski L, Martens J, Vanoirbeek $\mathrm{J}$, Hoet PH. Toxicity of nanoparticles embedded in paints compared to pristine nanoparticles, in vitro study. Toxicol Lett. 2015;232:333-339.

50. Smulders S, Luyts K, Brabants G, Landuyt KV, Kirschhock C, Smolders E, Golanski L, Vanoirbeek J, Hoet PH. Toxicity of nanoparticles embedded in paints compared with pristine nanoparticles in mice. Toxicol Sci. 2014;141:132-140.

51. Soenen SJ, Manshian BB, Himmelreich U, Demeester J, Braeckmans K, De Smedt SC. The performance of gradient alloy quantum dots in cell labeling. Biomaterials. 2014;35:7249-7258.

52. Derfus AM, Chan WCW, Bhatia SN. Probing the Cytotoxicity of Semiconductor Quantum Dots. Nano Lett. 2004;4:11-18.

53. Choi O, Clevenger TE, Deng B, Surampalli RY, Ross Jr L, Hu Z. Role of sulfide and ligand strength in controlling nanosilver toxicity. Water Res. 2009;43:1879-1886.

54. Munari M, Sturve J, Frenzilli G, Sanders MB, Brunelli A, Marcomini A, Nigro M, Lyons BP. Genotoxic effects of CdS quantum dots and $\mathrm{Ag}_{2} \mathrm{~S}$ nanoparticles in fish cell lines (RTG-2). Mutat Res Genet Toxicol Environ Mutagen. 2014;776:89-93.

55. Zhang Y, Hong G, Zhang Y, Chen G, Li F, Dai H, Wang Q. $\mathrm{Ag}_{2} \mathrm{~S}$ quantum dot: a bright and biocompatible fluorescent nanoprobe in the second near-infrared window. ACS Nano. 2012;6:3695-3702.

56. Akhtar MJ, Kumar S, Murthy RC, Ashquin M, Khan MI, Patil G, Ahmad I. The primary role of iron-mediated lipid peroxidation in the differential cytotoxicity caused by two varieties of talc nanoparticles on A549 cells and lipid peroxidation inhibitory effect exerted by ascorbic acid. Toxicol In Vitro. 2010;24:1139-1147.

57. Barillet S, Jugan ML, Laye M, Leconte Y, Herlin-Boime N, Reynaud C, Carrière M. In vitro evaluation of $\mathrm{SiC}$ nanoparticles impact on $\mathrm{A} 549$ pulmonary cells: cyto-, genotoxicity and oxidative stress. Toxicol Lett. 2010;198:324-330. 
58. Mahmoudi M, Simchi A, Milani AS, Stroeve P. Cell toxicity of superparamagnetic iron oxide nanoparticles. J Colloid Interface Sci. 2009;336:510-508.

59. Sharma V, Shukla RK, Saxena N, Parmar D, Das M, Dhawan A. DNA damaging potential of zinc oxide nanoparticles in human epidermal cells. Toxicol Lett. 2009;185:211-218.

60. Fotakis G, imbrell JA. In vitro cytotoxicity assays: Comparison of LDH, neutral red, MTT and protein assay in hepatoma cell lines following exposure to cadmium chloride. Toxicol Lett. 2006;160:171-177.

61. Chaung W, Mi LJ, Boorstein RJ. The p53 status of Chinese hamster V79 cells frequently used for studies on DNA damage and DNA repair. Nucleic Acids Res. 1997;25:992-994.

62. Chen Z, Wang Y, Ba T, Li Y, Pu J, Chen T, Song Y, Gu Y, Qian Q, Yang J, Jia G. Genotoxic evaluation of titanium dioxide nanoparticles in vivo and in vitro. Toxicol Lett. 2014;226:314-319.

63. Darne C, Terzetti F, Coulais C, Fontana C, Binet S, Gaté L, Guichard Y. Cytotoxicity and genotoxicity of panel of single- and multiwalled carbon nanotubes: in vitro effects on normal Syrian hamster embryo and immortalized v79 hamster lung cells. J Toxicol. 2014;2014:872195.

64. Guichard Y, Fontana C, Chavinier E, Terzetti F, Gaté L, Binet S, Darne C. Cytotoxic and genotoxic evaluation of different synthetic amorphous silica nanomaterials in the V79 cell line. Toxicol Ind Health. 2016;32:16391650.

65. Kang SJ, Kim BM, Lee YJ, Chung HW. Titanium dioxide nanoparticles trigger p53-mediated damage response in peripheral blood lymphocytes. Environ Mol Mutagen. 2008;49:399-405.

66. Gangwal S, Brown JS, Wang A, Houck KA, Dix DJ, Kavlock RJ, Hubal EA. Informing selection of nanomaterial concentrations for ToxCast in vitro testing based on occupational exposure potential. Environ Health Perspect. 2011;119:1539-1546.

67. Nogueira DR, Mitjans M, Infante MR, Vinardell MP. Comparative sensitivity of tumor and non-tumor cell lines as a reliable approach for in vitro cytotoxicity screening of lysine-based surfactants with potential pharmaceutical applications. Int J Pharm. 2011;420:51-58.

68. Kong B, Seog JH, Graham LM, Lee SB. Experimental considerations on the cytotoxicity of nanoparticles. Nanomedicine (Lond). 2011;6:929-941.

69. Maccormack TJ, Clark RJ, Dang MK, Ma G, Kelly JA, Veinot JG, Goss GG. Inhibition of enzyme activity by nanomaterials: Potential mechanisms and implications for nanotoxicity testing. Nanotoxicology. 2012;6:514525.

70. Monteiro-Riviere NA, Oldenburg SJ, Inman AO. Interactions of aluminum nanoparticles with human epidermal keratinocytes. J Appl Toxicol. 2010;30:276-285.

71. Díaz B, Sánchez-Espinel C, Arruebo M, Faro J, de Miguel E, Magadán S, Yagüe C, Fernández-Pacheco R, Ibarra MR, Santamaría J, GonzálezFernández A. Assessing Methods for Blood Cell Cytotoxic Responses to Inorganic Nanoparticles and Nanoparticle Aggregates. Small. 2008;4:2025-2034.

72. Karlsson HL, Di Bucchianico S, Collins AR, Dusinska M. Can the comet assay be used reliably to detect nanoparticle-induced genotoxicity? Environ Mol Mutagen. 2015;56:82-96.

73. Shukla RK, Sharma V, Pandey AK, Singh S, Sultana S, Dhawan A. ROSmediated genotoxicity induced by titanium dioxide nanoparticles in human epidermal cells. Toxicol In Vitro. 2011;25:231-241.
74. Dong B, Li C, Chen G, Chen G, Zhang Y, Zhang Y, Deng M, Wang Q. Facile Synthesis of Highly Photoluminescent $\mathrm{Ag}_{2}$ Se Quantum Dots as a New Fluorescent Probe in the Second Near-Infrared Window for in vivo Imaging. Chem Mater. 2013;25:2503-2509.

75. Gu Y-P, Cui R, Zhang Z-L, Xie Z-X, Pang D-W. Ultrasmall Near-Infrared Ag2Se Quantum Dots with Tunable Fluorescence for in vivo Imaging. J Am Chem Soc. 2012;134:79-82.

76. Tang H, Yang ST, Yang YF, Ke DM, Liu JH, Chen X, Wang H, Liu Y. Blood Clearance, Distribution, Transformation, Excretion, and Toxicity of NearInfrared Quantum Dots Ag2Se in Mice. ACS Appl Mater Interfaces. 2016;8:17859-17869.

77. Jebali A, Hekmatimoghaddam S, Kazemi B. The cytotoxicity of silver nanoparticles coated with different free fatty acids on the Balb/c macrophages: an in vitro study. Drug Chem Toxicol. 2014;37:433-439.

78. Hocaoglu I, Çizmeciyan MN, Erdem R, Ozen C, Kurt A, Sennaroglu A, Acar HY. Development of highly luminescent and cytocompatible near-IRemitting aqueous Ag2S quantum dots. J Mater Chem. 2012;22:14674-14681.

79. Gopinath P, Gogoi SK, Sanpui P, Paul A, Chattopadhyay A, Ghosh SS. Signaling gene cascade in silver nanoparticle induced apoptosis. Colloids Surf B Biointerfaces. 2010;77:240-245.

80. Sherr CJ. Principles of Tumor Suppression. Cell. 2004;116:235-46.

81. Ryan BM, O'Donovan N, Duffy MJ. Survivin: A new target for anti-cancer therapy. Cancer Treat Rev. 2009;35:553-562.

82. Chougule M, Patel AR, Sachdeva P, Jackson T, Singh M. Anticancer activity of Noscapine, an opioid alkaloid in combination with Cisplatin in human non-small cell lung cancer. Lung Cancer. 2011;71:271-282.

83. Gao C, Wang AY. Significance of Increased Apoptosis and Bax Expression in Human Small Intestinal Adenocarcinoma. J Histochem Cytochem. 2009;57:1139-1148.

84. Timmer JC and Salvesen GS. Caspase substrates. Cell Death And Differentiation. Cell Death Differ. 2007;14:66-72

85. Youle RJ and Strasser A. The BCL-2 protein family: opposing activities that mediate cell death. Nat Rev Mol Cell Biol. 2008;9:47-59

86. Jänicke RU, Sprengart ML, Wati MR, Porter AG. Caspase-3 is required for DNA fragmentation and morphological changes associated with apoptosis. J Biol Chem. 1998;273:9357-9360.

87. Porter AG, Jänicke RU. Emerging roles of caspase-3 in apoptosis. Cell Death Differ. 1999;6:99-104.

88. Saquib Q, Al-Khedhairy AA, Ahmad J, Siddiqui MA, Dwivedi S, Khan ST, Musarrat. Zinc ferrite nanoparticles activate IL-1b, NFKB1, CCL21 and NOS2 signaling to induce mitochondrial dependent intrinsic apoptotic pathway in WISH cells. Toxicol Appl Pharmacol. 2013;273:289-297.

89. Farnebo M, Bykov VJ, Wiman KG. The p53 tumor suppressor: A master regulator of diverse cellular processes and therapeutic target in cancer. Biochem Biophys Res Commun. 2010;396:85-89.

90. Blanc-Brude OP, Yu J, Simosa H, Conte MS, Sessa WC, Altieri DC. Inhibitor of apoptosis protein survivin regulates vascular injury. Nat Med. 2002;8:987-994

91. Marusawa H, Matsuzawa S, Welsh K, Zou H, Armstrong R, Tamm I, Reed JC. HBXIP functions as a cofactor of survivin in apoptosis suppression. EMBO J. 2003;22:2729-2740.

92. Fuentes-Prior P, Salvesen Guy GS. The protein structures that shape caspase activity, specificity, activation and inhibition. Biochem J. 2004;384:201-232. 